УДК 394

\title{
Off-the-Grid Life of Arctic Nomads: \\ Social Generating of Electricity \\ in the Northern Yamal
}

\author{
Dmitry V. Arzyutov* \\ Peter the Great Museum of Anthropology \\ and Ethnography (Kunstkamera) RAS \\ 3 University emb., St. Petersburg, 199034, Russia
}

Received 02.03.2019, received in revised form 02.08.2019, accepted 09.08.2019

This article deals with the ethnographic analysis of the history and social life of electricity among Nenets in the Yamal Peninsula. Based on historical documents and field data the author reconstructs a history of the electrification of the northern part of the peninsula. This work also includes the reflections on social and cultural meanings of electricity among Nenets in and out the tundra. Through these historical and current dynamics, the author suggests analysing the life of electricity in off-the-grid settings through the lens of transnational technological entanglements in the Arctic.

Keywords: ethnography, electricity, nomads, Nenets, development of the North, Arctic.

This work has been supported by the RSF project "Energy of the Arctic and Siberia: The Use of Resources in the Context of Socio-Economic and Environmental Changes" (No. 18-1800309).

Research area: ethnography, ethnology and anthropology.

Citation: Arzyutov, D.V. (2019). Off-the-grid life of Arctic Nomads: social generating of electricity in the Northern Yamal. J. Sib. Fed. Univ. Humanit. soc. sci., 12(8), 1356-1373. DOI: 10.17516/1997-1370-0454.

(C) Siberian Federal University. All rights reserved

* Corresponding author E-mail address: darzyutov@gmail.com

ORCID: 0000-0003-3782-9296

This work is licensed under a Creative Commons Attribution-NonCommercial 4.0 International License (CC BY-NC 4.0). 
"Provoda-provoda-provodochki

Sluzhat lyudyam vezde i vsegda.

Net na karte strany dazhe tochki,

Ne sluzhili by gde provoda..."

From the "UralCabel" song by Evgenii Shikunov

\section{A touch of the "Mechanical Light": in lieu of introduction}

Nina Ivanovna Gagen-Torn (1900-1986), a Soviet ethnographer and historian of ethnography in the twilight of her life worked on a book about the lives and works of her friends and colleagues, the first generation of Soviet ethnographers of the North. She was able to tell only a small part of what she had initially intended to. In her recently published diaries and notes, the reader might be surprised by a phrase she brightly formulated about what her book was going to be about, "how [students of the 1920 s - D.A.] were dropped off to test (R. proschupat') the life that was untouched by the mechanical light of the 20th century yet" (Gagen-Torn, 2013: 271, italics added D.A.). "Mechanical light"... is perhaps the most accurate metaphor of the early Soviet era that was inspired by the pathos of technological innovation as a way to speed up the building of communism. However, this "mechanical light" reached the northern outskirts of the country so slowly that in most cases it remained a propaganda message. The Arctic settlements started using electricity decades later, and not through a shared wire system, but with diesel generators which are a compromise between the so-called Large Technological Systems (LTS) often performing as national ones (Coopersmith, 1992; Hughes, 1993) and local enterprises.

The northern part of Yamal (Western Siberia) still remains a space with very limited access to electricity with the exception of the internal "islands" which are provided by huge electric generators in the Se-Yakha settlement, the port of Sabetta, trading posts of Tambey and Yakhada-Yakha. The territory between these islands which is in use by the Nenets nomads is internally intertwined by complex gift-giving relationships, a significant part of which is linked to the idea of obtaining ( $\mathrm{R}$, dostavat') petroleum or gas condensate. Thus, only thanks to interpersonal and trade skills one could start a generator in a chum (tent) (a field essay on petrol exchanges in tundra; Arzyutov,

"Wires — wires - lovely wires / They serve people everywhere and every time. / There's not even a point on the map of the country / Where wires would not serve ..." Available at: https://youtu.be/gCUkDlq _Tiw (Accessed: October 14, 2018) 
2017). However, behind these exchanges within friendship and kinship networks there are human-landscape-animal relations which materialize as exchange equivalents (the number of tails / barrels of fish or of reindeer carcasses). Thus, both social experience and skills of reindeer herding and hunting create the nomad's way to that "mechanical light".

This combination of an integrated LTS and local initiatives is the focal point of this article where I consider electricity as a living social matter that depends on personal soft skills, as well as on reindeer herding and fishing. In order to understand the life of this matter, I will discuss the following issues. First, I will present the early Soviet electrification projects and more widely — the use of energy in the Arctic through the history of Nenets lands. Secondly, I will present how electricity was conceptualized by the Soviet ethnographers, who understood electrification through the imagined shift from animism to materialism of indigenous Arctic people. Thirdly, I will present the social relations with geological parties and oil and gas shift workers or pidichi as they are known in Nenets language. This social and cultural palimpsest of electricity-oriented projects allows to significantly rebuild indigenous material cultures including there barrels for petrol, sledges for transporting the electrical equipment and many other "innovations". The conclusion of the article is dedicated to what is happening in the tundra today when the autonomous access to electricity in a combination with the heritage of "the development of the North" affects the everyday diplomacy of reindeer herders.

The theoretical ideas of the anthropology of energy were formulated by Leslie White in his "The Science of Culture: A Study of Man and Civilization", where he anthropologically reframed the idea of entropy in its connection with discussions about the second law of thermodynamics. Relying on the works of physicists, White re-asserted that energy is neither created nor annihilated, but merely transforms (White, 1949: 374). Combining physics and anthropology White certainly made his life within the discipline rather complex. His ideas were in opposition to historicism and individualism, dominated in American anthropology of that time (Boyer, 2014: 312). Richard Adams and his presidential message to the American Anthropological Association in 1977 was the only one who attempted to reanimate White's anthropology through new conceptualizations of energy conceptualization (Adams, 1978). In a broader context, both White and Adams wrote and published their works during the Cold War, when, according to Per Högselius (Högselius, 2012), Europe became dependent on energy resources of the Soviet Union. The Arctic played and still plays an exceptional role in this. 
Anthropologists reveal two problems related to electricity. On the one hand, the access to electricity in rural areas causes social inequality, as Tanya Winther perfectly depicts in her book about the electrification of the Uroa village in Zanzibar (Winther, 2008). On the other hand, the production of electricity significantly impacts on the environment that in turn provokes emerging of new colonialisms.

\section{In the shadow of the GOELRO plan}

In the development of the concept of indigeneity in the Russian North, light has always played a key role. Even in "The Tale of Bygone Years", the Samoyeds have been already depicted as a group living "in the midnight countries". The darkness and backwardness were the synonymous of metropolitan conceptualizations for indigeneity. The cited above passage from Gagen-Torn's diary in some way repeats this trope. Soviet modernity prioritized a project on enlightment of the country which was partly implemented through the electrification (GOELRO) following Lenin's moto, "Communism is the Soviet power plus electrification of the whole country".

Social and cultural ideas behind the GOELRO plan were aimed at unifying the country by connecting the center and its outskirts. The GOELRO plan also included radio communications installed throughout the Soviet Union including Yamal. Based on technological history of these innovations, I am inclined to think that right from the beginning the Soviet power was spread through the wires and radio waves that connected people and created a certain technoscape for the circulation of propaganda and utopian ideas of socialism (cf. Wells, 1921: 158-160). Perhaps, the artist Pavel Filonov was the best at depicting that utopia. His GOELRO work contains Lenin's figure in the center of a complex web of wires. As Jonathan Coopersmith, a historian of Russian electrification writes,

"Electrification formed the foundation of Bolshevik plans for economic and societal reconstruction: it would eliminate the town-country split, create a communist society in Russia, and lead to a similar transformation of the capitalist world while the electrical engineers received official support for their utopian visions." (Coopersmith, 1992: 151).

The Soviet Arctic was not a focal locus for the electrification project due to its remoteness and a certain isolation. As far as we know today, the first electric generator appeared in the Soviet Arctic in 1934 (Varshavskiy, 1937: 75). Only polar stations and some cultural bases and trading posts could afford such luxury technological innovations as electric generators. According to Varshavskiy, their engines run on 
petrol, which was (and still remains) incredibly expensive in the tundra. One of the solutions to such high cost was in designing a wind turbine. Using this typical "wild" energy of the northern landscape seemed to be quite appropriate also for creating northern transport, namely wind-driven vehicles (Travin, 1939). A brief history of wind-driven vehicles from Nezhdanovskii's aerosleges to "1980-E" snowmobile has been recently analyzed by Nikolai P. Garin and Svetlana G. Kravchuk (Garin, Kravchuk, 2018: 61-119). The stories they told in their book could be also enriched by two episodes from the Nenets tundras. I here refer to the project of wind-driven vehicle (R. vetrokhod) of Nikolai Dmitrievich Travin and a draft of the project of aerosledge made by Grigory Davydovich Verbov (MAE \# I-1215-210 / 1-3) (Fig la and b). They both were students of Bogoraz and Sternberg and both spent quite long time in the North with Nenets. Judging by the drafts, those projects were driven Yflj by the design of vechiles developed by indigenous people and Russian settlers. Paradoxically, being ethnographers, or as Bogoras baptized them, "missionaries of new way [Soviet] of living" the authors regarded their inventions primarily for field scholars living their indigenous field cooperators with traditional reindeer or dog sledges.

In fact, this is not only an episode of the history of domesticating energy but also the first attempts at future "snowmobile revolution" in the North (Pelto, 1973). The very idea of using wind in electricity production in the Arctic occurred to Fridtjof

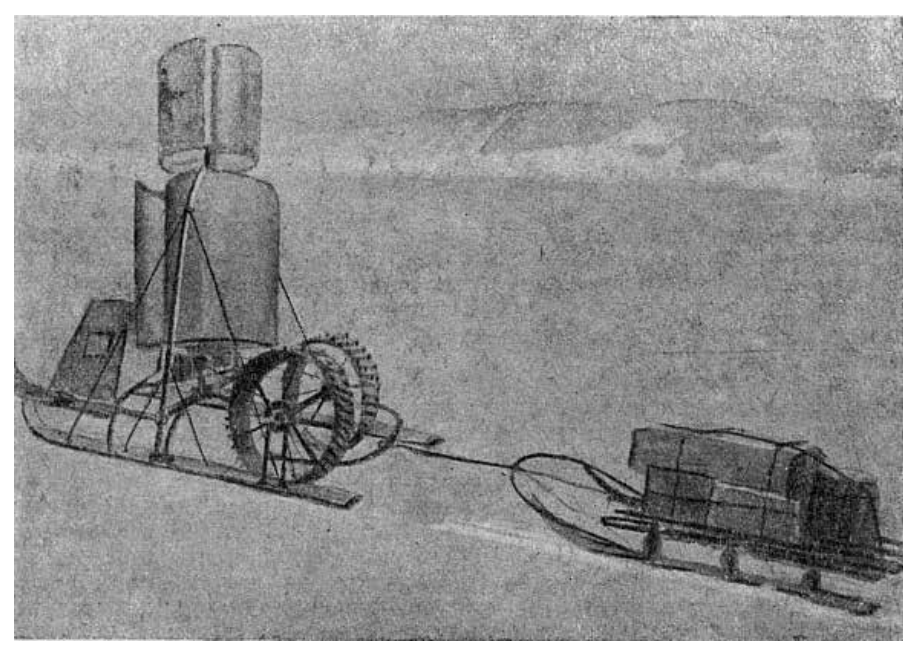

a

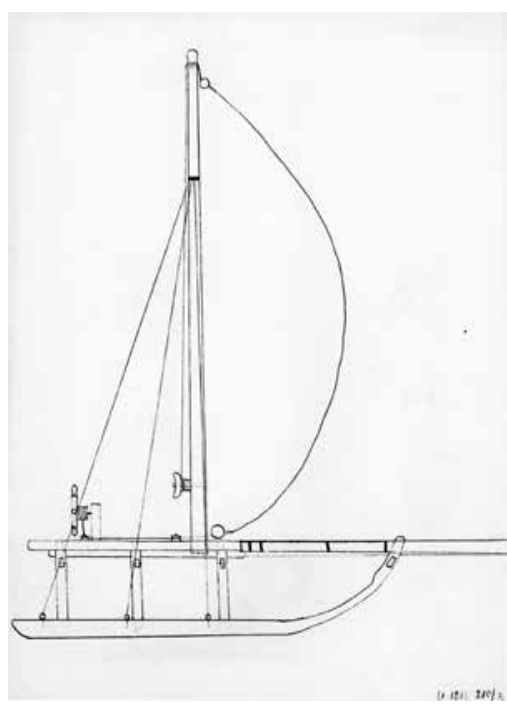

$\mathrm{b}$

Fig. 1a and b. The project of N. Travin [1939: 113] and the project of G. Verbov [MAE \# I-1215-210/3] 
Nansen who during his first Fram expedition in 1893 had already used wind engines producing enough electricity for a few incandescent lamps.

All those projects and ideas conversations seemed to be quite real to the Soviet metropolitan bureaucrats and consequently engineers and they tackled the projects of exploring wind in the production of not only vehicles, but also electricity in the North (Rozentul, 1936; Rozentul, 1937). All this suggests that Soviet modernity, for which the creation of new energy landscape was a central idea, which partly resulted not only in centralizing the energy systems, but also in a sufficient level of both isolation and atomization of communities. The problem of the use of wind energy in Yamal still remains unsolved for local people and enters public discourse in the 1990s (Anon., 1993-95). However, despite the autonomy, the delivery of generators to trading posts, cultural base (R. kul'tbaza) or red tent (R. krasnyi chum) was initiated merely for propaganda purposes. Much later, trading posts and the "red tents" remained those few places in the tundra where electricity was produced mainly for cinema purposes (Anon., 1958). Such spaces Madeleine Akrich in the following way, "the electricity network made it possible for the state to create its own space (the space of common interests) that could not be appropriated by anyone else" (Akrich, 1992: 214). After the collapse of Soviet Union, the same practices were appropriated by Protestant missionaries who employed generators in Yamal tundras particularly for showing religious films.

As I mentioned above, in the Soviet era the "islands" of cables and engines involved the reindeer herders into state propaganda and state-controled energetic systems. This entanglement might remind the Portuguese colonization described through the connectivity of ships in the open sea and long-distance metropolitan governance that was described by John Law (Law, 1986).

\section{Animism - Electricity - Materialism}

For the pioneer of Soviet ethnography, Vladimir Bogoraz, as well as for many of his students and colleagues, religion was as a certain obstacle in the way of building a socialist society in the North. In his 1932 article (Bogoraz-Tan, 1932), Bogoraz supports his argument with the field data of one of his students Georgii N. Prokofiev who could not agree on what living and non-living matters were during his fieldwork among Selkups and later among Nenets and the discussions with the pupils in classrooms (Prokofiev, 1927). Apart from its philosophical background, this question turned out quite important at the time of active production of textbooks for the northern boarding schools. The textbooks might have explanation of various 
abstract ideas, which however were very diverse and far from what the Moscow and Leningrad-based scholars thought. Bogoraz as one of the leaders of the Committee of the North was aware of such problems and tried even to conceptualize it in his articles. He believed that it was necessary to "make" the people of the North materialists. He wrote, "industrialization is the best way to fight against animism in the far North-East. [...] Physical and chemical devices even the simplest ones can challenge the animistic worldview [of indigenous people of the North] much deeper than the most talented lectures. A photograph of the Ostyak-Samoyeds' [now Selkups - D.A.] school took by Prokofiev shows us the students assembling a radio that they made at home" (Bogoraz-Tan, 1932: 150-151) (Fig. 2). A few years later, in his never-published book "The Stages of Shamanism Development" (1936) Bogoraz would write that, "Cultural bases always arise the question to what kind of power drives these Soviet-made machines and devices. For example, a movie-machine, radio, electric light, gramophone, tractors, whether these mechanisms and machines are driven by simple mechanical force or have some kind of devil, a supernatural engine hidden in the heart" (Bogoraz-Tan, 1936: 492).

These pictures as well as the citations above bear the idea that technology and industrialization indeed were necessary conditions in making a socialist reality where

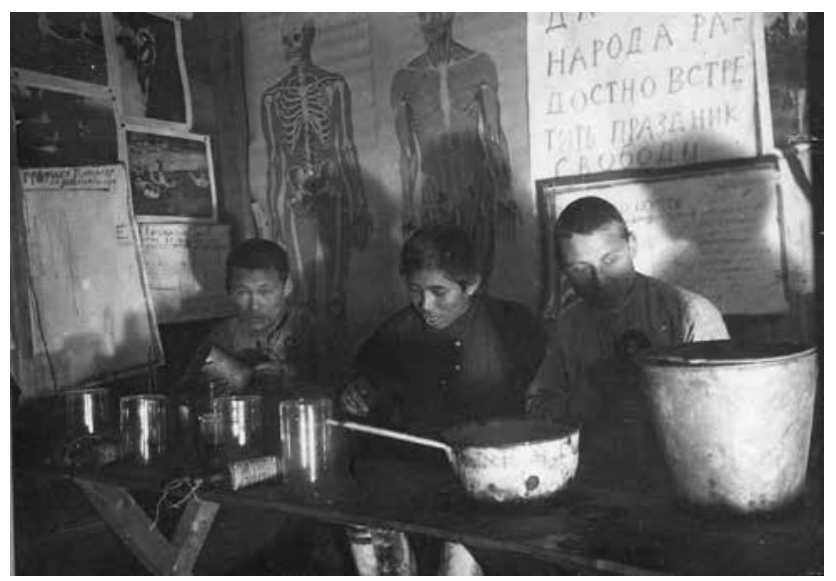

Fig. 2. From animism to materialism. Shamanic "little devil" driving a polar bear for a shamanistic ritual in the animated film "A Samoyed Boy"1 and Selkup schoolchildren assembling radio: Prokofiev, 1931: 147, Popov, 1932: 16-17 (inset)²; MAE \# I-1177-89.

\footnotetext{
“A Samoyed Boy". Sovkino, 3rd-production. Animated film. 1928. (IMDbID2111403).

2 Victorin Popov points out that the photo was taken at Khoseda-Khard, "The Nenets-Komsomol members in the laboratory."
} 
all communities would share a single materialistic epistemology. Electricity as both a phenomenon and infrastructure fully reflected the very concept of modernity which was opposed to any religiosity. In fact, this belief remained strong enough until the Khrushchev era, a new round of the fight against religion (Luehrmann, 2015). For example, at the Museum of Religion and Atheism in Leningrad the 1964 exposition "Overcoming the Religious Survivals [R. perezhitok] in the USSR in the period of Massive Construction of Communism" showed the topic of electricity as one of the most conceptual continuing to putting the stress on the famous Lenin's formula on communism and the Soviet power (Anon., 1964).

Here I would like just remind the reader of an episode from a brilliant article of David Sneath which describes the ethnography of electrification of Mongolia. One of its protagonists having seen inexpensive light bulbs in the store, which we turned on, was simply shocked by the electric light. He decided to buy a hundred bulbs and bring them to his camp. However, already there he realized that they did not work of their own and his brother, who was educated explained to him that they required the electrical infrastructure that made a light bulb to shine (Sneath, 2009: 77). Sneath describes this episode as a "metonymic field" emphasizing that the very concept of Lenin's electrification can be considered as a metonymy of development and enlightenment. What is important is that already at a cultural base, as I showed in Fig. 2b, indigenous people created the concept of this infrastructure themselves (or what is known as LTC) which despite the declared national level nevertheless continued remaining relatively local, observable on the territory of a "red tent" or cultural base. Returning to Bogoraz's concept that electricity and technology could create materialistic epistemologies, we can say that this hand-made electricity was an the expected form of materialism. Moreover, the concept of atomization of electricity and its local production played a certain role in the future.

\section{...And along came pidichi}

In the 1970s, there was a new round of development of the North (Agranat, Loginov, 1976), which caused a radical change both the national economy and economic relations of indigenous people (Rytkheu, 1970). The Arctic exploration changed the nature of the North and triggered the first debates about the Arctic ecology and the emergence of large-scale government and international environmental programs, such as "Man and the Biosphere". Against its backdrop, there was a real wave of indigenous environmental movements against massive constructing the 
hydroelectric power plants and a new colonization of the land by energy corporations (see, for example, Cruikshank, 1972). The Soviet Siberia would get involved in this at a later stage and mainly in the southern part got involved. But despite the political context of industrial development, the advent of geological expeditions to the Arctic brought new materials and even architecture to many regions of the Arctic, namely mobile houses for shift workers, building materials and others. (Fig. 3). All these after the expeditions finished their work were left behind. These "Soviet debris" (SsorinChaikov, 2016) allowed reindeer herders to significantly change their material culture (for the Evenki of Transbaikal; Davydov, 2012). Combining the micro-ethnography of electricity and what is known in the technological history as LTS, we can notice that the formation of local electricity infrastructures began at the very time when the Arctic and Yamal, in particular, became an important part of transforming the Soviets into the main supplier of gas to Europe (Högselius, 2012). Thus, the abandoned objects and building materials exchanged by the shift workers provide us with understanding the relationship of micro- and macro-levels of analysis.

These "Soviet debris" were formed in the tundra, first owing to geologists, and then to the shift workers - pidichi in Nenets (from the word expedition). This term exists simultaneously with another one, better known in Nenets ethnography - lutsa usually meaning all those who came from the "mainland", all "non-indigenous" those who do not fall into a vast set of ethnonyms in Nenets language.

Fig. 3. "Soviet debris": an abandoned power line between two drilling towers of the Soviet era1. The northernmost part of Yamal. Tambey Tundra. Yamal. May 2018. Photo by the author

\footnotetext{
It might remind Wassily Kandinsky who in his book "Point and Line on the Plane" uses the metaphors of forests to electric masts (Kandinsky, 1947: 103).
} 
It must be said, that the pidichi left a significant mark in the history of Yamal architecture both in settlements and in the tundra. Bringing the idea of mobile architecture to the North, they were able to fill the gap in state architectural programs. The pidichi built entire neighborhoods in settlements out of huge tanks. So, in Se-Yakha, one even today can see the remains of such a neighborhood known as "Bochkaryovka". The tanks insulated and sheathed inside with wooden planks, with small windows and additional entrance halls became home for hundreds of families on the Yamal Peninsula for many years. During my 2018 field work, I took a picture of perhaps the most northern "barrel" on the peninsula, at the Yakhada-Yakh trading post (Fig. 4).

However, residential barrels came along with the barrels designed for fuel transportation. The latter as remains of the Soviet development of the North has been one of the the main subjects for the Russian environmental politics in the North over the past few years under the project on cleaning up the Arctic ${ }^{1}$. The Soviet heritage, within these discussions and governmental decisions, is seen precisely as an accumulation of scrap metal, mainly barrels. A historian of the Nenets everyday life would easily notice that the first barrels that came to the tundra were converted into mobile metal stoves, commonly known as "burzhuika". Reindeer herders with whom I had to talk during my fieldwork told me in detail about which barrels were better and why. For them,

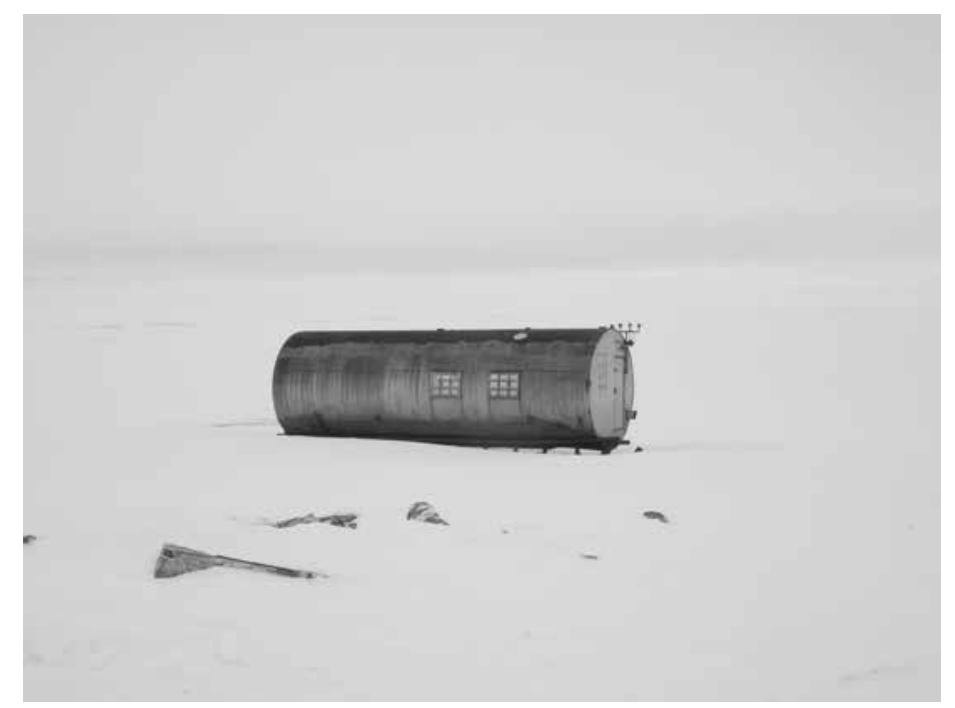

Fig. 4. The most northern "barrel" on the Yamal Peninsula. Yakhada Yakha trading post. Photo by D. V. Arzutov. 2018

Available at: https://www.rgo.ru/ru/proekty/ochistka-arktiki 
this state scrap metal has quite a material meaning: the barrels of the 1960 and 1970 s perfectly suit for storing petrol, but not quite appropriate for its transportation, too heavy because of the thickness of walls. Modern "Gazprom" barrels, on the contrary, are of little use in the tundra due to the thinness of wall metal.

Pidichi also brought to the tundra such materials as plywood, geotextile and others. It is worth especially noticing about darnit (geotextile). Darnit or dornit is a synthetic non-woven material that is used mainly as a heater for tent (chum) covers. The name comes from the abbreviation of the Road Research Institute (DorNII, known today as RosDorNII), which created this material for such large socialist projects such as Baikal-Amur Mainline (Arzyutov, 2017: 323).

Planks and plywood became the basis for making sleighs for snowmobiles (Fig. 5, 7) and special entrance halls for the nomadic chums, called seni, which are widespread mainly in the north of the Yamal Peninsula.

This practice of reuse is documented by the polar workers in a certain colonial way, "Before the Perestroika, there were about twenty polar stations under the administration of Dickson island station. Now, they are may be seven or eight. Even these are going to be closed or closed under the pretext of conservation. But after closing down, the local Nenets came to Vilkitsky Island on snowmobiles and [after this] the station could hardly be restored. They disassemble the diesel engine and take the equipment away. That is complete devastation."

\section{Handmade electricity}

Despite all the attempts, Yamal like many other northern regions of the USSR has never been fully electrified. Looking at different nomadic camps of the peninsula from a helicopter one can see how electric wires entangle small "islands" of settlements. If ropes create stable (in terms of space, not time) structures in the tundra such as corral or chums (Arzyutov, Okotetto, 2018), the electric wires as the signs of modernity which used be visible but now are often hidden. As an anthropologist of infrastructure Brian Larkin writes, "We often see computers not cables, light not electricity, taps and water but not pipes and sewers" (Larkin, 2013: 329).

With the collapse of the USSR, the atomization of social life has been combined with obschina (community) movement of indigenous peoples. It is noteworthy that it was at this time when generators and snowmobiles became the main gifts received by

\footnotetext{
See: https://les.media/articles/151332-istoriya-meteorologa-s-russkoy-polyarnoy-stantsii
} 


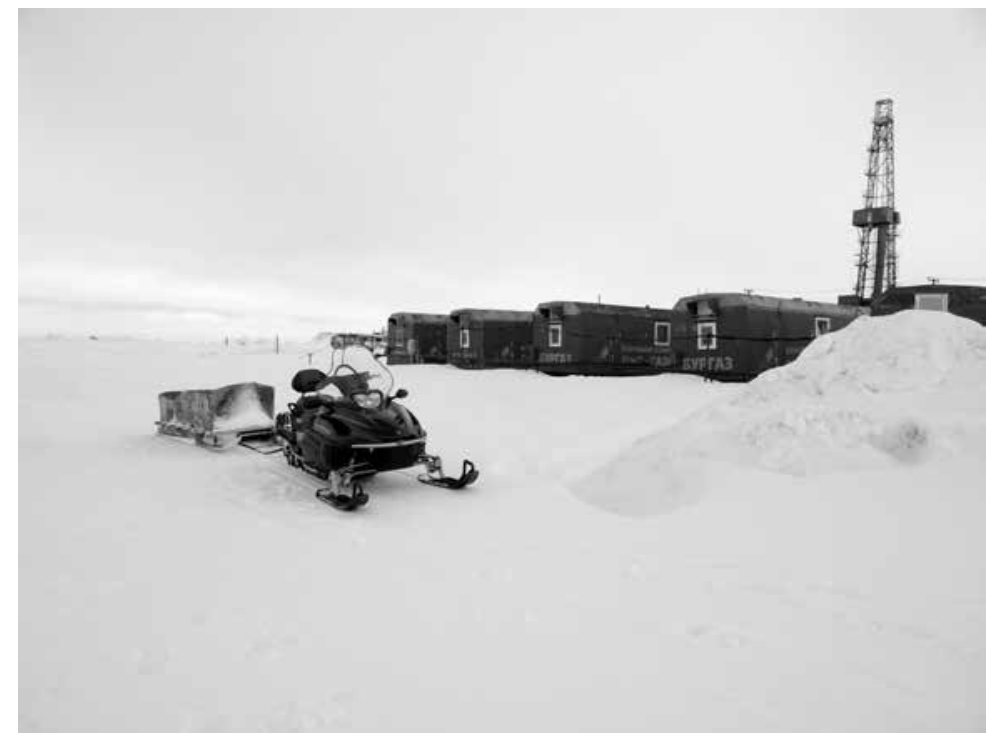

Fig. 5. During negotiations. The Nenets snowmobile with a sleigh at one of the Yamal gas drill towers. Tambey Tundra. June 2018. Photo by the author

the reindeer herders from oil and gas companies or from the local officials. This practice is still alive. For example, at Portsy-Yakha trading post in 2016, a petrol generator was the first-place trophy for reindeer sleigh races.

Snowmobiles and generators can only partially be considered as innovations for the local population. As I mentioned above, many materials including abandoned petrol barrels were already the resource that helped integrate snowmobiles or generators into the internal fabric of abandoned landscapes as well as the skills acquired from pidichi.

There is another coincidence mentioned by the reindeer herders. The depletion of petrol in abandoned barrels coincided with the arrival of new pidichi, shift workers who work on the gas drill towers. They became a new source of petrol for the reindeer herders through the fish and reindeer meat exchanges. (Fig. 5).

The creativity of reindeer herders helped to combine the early-Soviet ideas of electricity with the late-soviet materiality and the modern paternalistic relations of oil and gas companies. This connection has opened up new forms of interaction with the outside world. Observing the passion of reindeer herders to watch movies on their laptops and DVD players, some ethnographers and designers propose calling the modern nomadic camp "cyber" (Golovnev et al., 2015: 64-65), a place where nomadism gains an additional visual perspective and materialization. However, it is 
fair to say that the implicit evolutionary paradigm (from a traditional camp to a cyber one), as well as the nostalgic remark that the "tundra has been spoiled by generator" can hardly explain the social life of electronic devices and more broadly - electricity in the tundra, which I could see in the north ern part of Yamal, and which is far from destroying the folk tradition. The models of exchanges with shift workers lead to a kind of aesthetic systems exchange: the films watched by the shift workers are copied and come to nomadic tents. Thus, being originally relatively autonomous, the system of electric generators in the social space is closely intertwined with the outside world. It is here that the selection of favorite TV shows and, to a certain extent, visual representations of life in "Russia", an urban space in the western part of the country, is being made.

The electrical equipment found its place among the Nenets things. As Zoltan Nagy writes, the eastern Khanty put the screen in such a way as to be visible from most living parts inside the house (Nagy, 2013). The sacred part of a Nenets chum - si - turned out to be the most suitable place for a laptop or less often a DVD player (see Fig. 6b). It is noteworthy that the desire for compactness and mobility of modern devices found a response in the tundra, making it a very modernistic space.

However, the electrical equipment fell out of the usual order of things in nomadic life. Snowmobiles (or "Burans") that appeared at the end of the Soviet era have changed the Nenets economy and nomadism. Looking at these changes from a historical perspective one could notice that newly designed snowmobile sleds out of

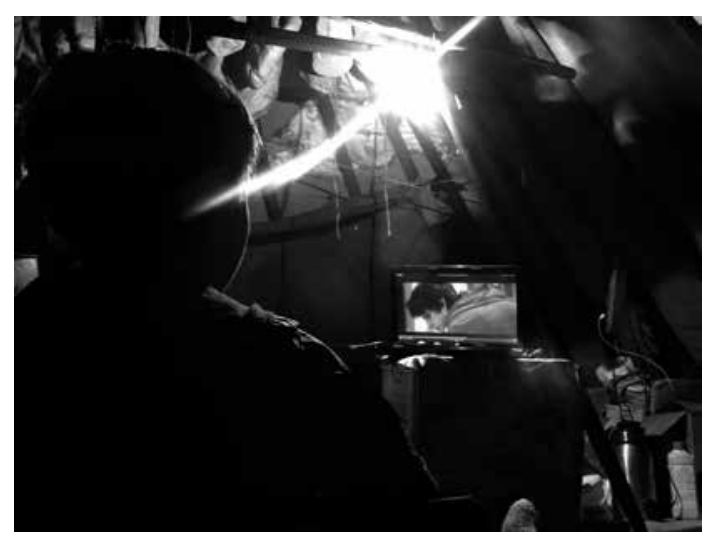

$\mathrm{a}$

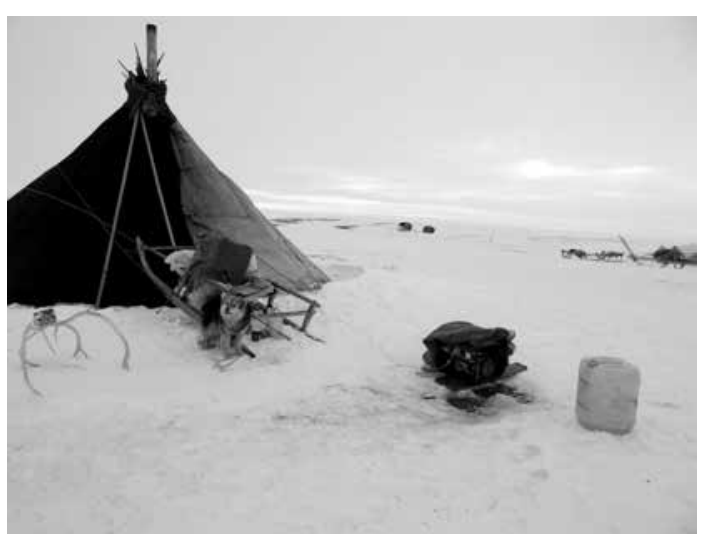

$\mathrm{b}$

Fig. $6 \mathrm{a}$ and $6 \mathrm{~b}$. From a mobile petrol generator near the tent to a moving picture on a laptop screen and a light bulb ("Ilyich's bulb", as the locals call it).

Tambey Tundra. Yamal. May 2018. Photo by the author 


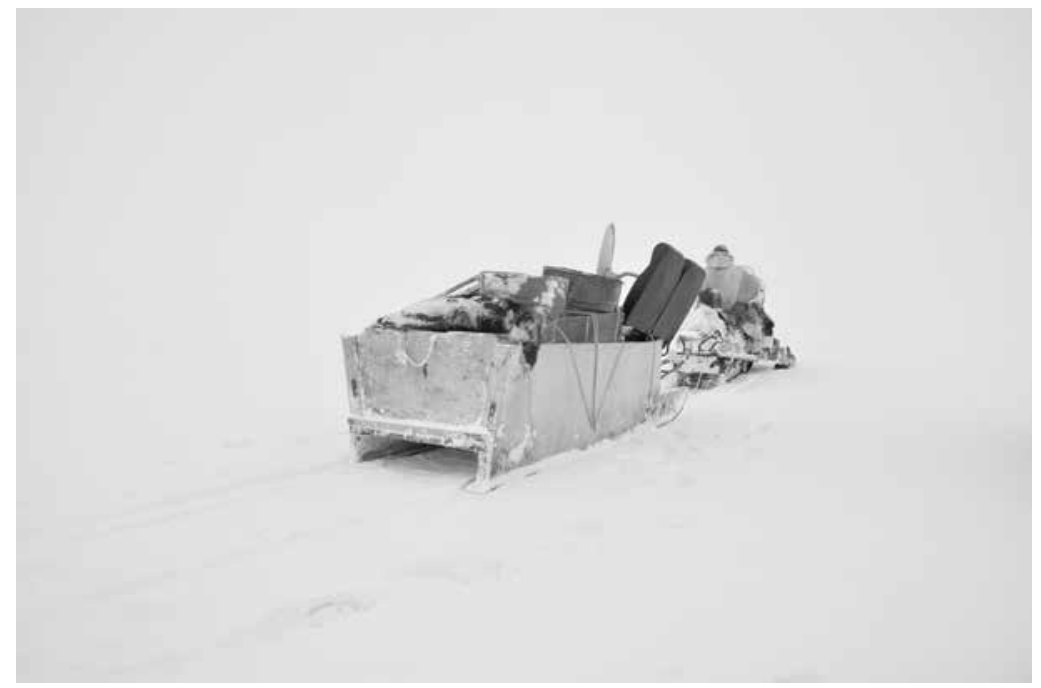

Fig. 7. Snowmobile sled with electrical equipment.

Tambey Tundra. March 2015. Photo by the author

pidichi's materials became a suitable place for transportation of electrical equipment (see. Fig. 7). Thus, nomadic way of living has been only extended towards certain innovations, which found their own place in an assemblage of things.

This assembly of things is rapidly growing. In my last fieldwork in 2018, I witnessed the use of a huge number of different electronic tools, such as an angle grinder, also known in Russian as "bolgarka". Moreover, some chums become mobile workshops where people from neighboring chums come to repair their snowmobile, generator and other electronic devices.

\section{Conclusion}

Despite some historical continuity with the GOELRO plan, the modern atomized electrification turned out to be quite opposite, finding a balance between the nomadic way of life and access to the national and transnational mediascapes (according to Appadurai). However, the inventions and everyday practices of reindeer herders can significantly expand our ideas about the social life of electricity. We see this life of non-alienated electricity through face-to-face negotiations with pidichi. Thus, the electricity here is a certain vibrant matter rather than as an alienated object familiar to a city dweller. Today we can observe the metamorphoses in the electricity use in the tundra, from DVD players to laptops, and to the nomadic electric workshops. All these changes, sometimes in a paradoxical way, support the nomadic way of life, expanding 
its understanding towards a complex interweaving of local and global, national and transnational where the technologies and ways of knowledge of locals and newcomers are in a lively dialogue.

\section{References}

Adams, R.N. (1978). Man, Energy, and Anthropology: I Can Feel the Heat, But Where's the Light? In American Anthropologist, 80 (2), 297-309. DOI: 10.1525/ aa.1978.80.2.02a00030.

Agranat, G., Loginov, V. (1976). Ob osvoenii severnykh territorii [On the Development of the Northern Territories]. In Kommunist [The Communist], (2), 39-48.

Akrich, M. (1992). The De-Scription of Technical Objects. In Shaping Technology/ Building Society. Studies in Sociotechnical Change, Cambridge, Mass, London, The MIT Press, 205-24.

Anon, (1958). Ust'-Iuribeiskii krasnyi chum [Ust'-Uiribei Red Tent]. Moscow, Sovetskaia Rossiia.

Anon. (1964). Ekspozitsionnyi plan otdela "Preodolenie religioznykh perezhitkov v SSSR v period razvernutogo stroitel'stva kommunizma" [The Exhibit Plan of "Overcoming the Religious Survivals in the USSR in the period of Massive Construction of Communism"]. In GMIR [State Museum of the History of Religion].1/2/138

Anon. (1993-95). Protokoly Iamalo-Nenetskoi okruzhnoi komissii ekologii i prirodnykh resursov [The Reports of Yamal-Nenets Region Commission for Ecology and Natural Resources], In GAIaNAO [State Archive of Yamal-Nenets Autonomous Region]. 336/1/17

Arzyutov, D.V. (2017). Oleni i/ili benzin: esse ob obmenakh v severo-iamal'skoi tundre [Reindeer and/or Pertol: An Essay on Exchanges in Northern Yamal Tundra]. In Sotsial'nye otnosheniia $v$ istoriko-kul'turnom landshafte Sibiri [Social Relations in the Historical and Cultural Landscapes of Siberia]. Saint Petersburg, MAE RAN, 314-348.

Arzyutov, D.V., Okotetto, Kh. Kh. (2018). Sviazyvaia veshchi, zhivotnykh i liudei: k sotsial'noi topologii nenetskikh uzlov [Tying Things, Animals and Humans Together: Towards Social Topology of Nenets Knotes]. In Arkheologiia Arktiki [Archaeology of the Arctic], 5, 89-106.

Bogoraz-Tan, V.G. (1932). Religiia kak tormoz sotsialisticheskogo stroitel'stva sredi malykh narodnostei Severa [Religion as an Obstacle of Socialistic Building among the Small Peoples of the North]. In Sovetskii Sever [The Soviet North], (1-2), 142-157. 
Bogoraz-Tan, V.G. (1936). Stadii razvitiia shamanstva [The Stages of the Development of Shamanism]. In GMIR [State Museum of the History of Religion]. 1/1/33

Boyer, D. (2014). Energopower: An Introduction. In Anthropological Quarterly, 87 (2), 309-33. DOI: 10.1353/anq.2014.0020.

Coopersmith, J. (1992). The Electrification of Russia, 1880-1926. Ithaca and London, Cornell University Press.

Cruikshank, J. (1972). Cultural Responses in the Alaska Village Electric Cooperative in Alaska Native Villages. In Arctic Anthropology, 9 (1), 35-42.

Davydov, V.N. (2012). People on the Move: Development Projects and the Use of Space by Northern Baikal Reindeer Herders, Hunters and Fishermen, PhD Thesis, Aberdeen: University of Aberdeen.

Gagen-Torn, N.I. (2013). Ieroglif $i$ znak vekam [The Hieroglyph and the Sign for Time]. Moscow, Fond Sergeia Dubova.

Garin, N.P., Kravchuk, S.G. (2018). Skol'ziashchii transport dlia Rossiiskogo Severa: istoriia idei (al'bom-monografiia) [Sliding Vehicles for the Russian North: History of Ideas (album-monograph)]. Ekaterinburg, UrGAKhU.

Golovnev, A.V., Perevalova, E.V., Abramov, I.V., et al. (2015). Kochevniki Arktiki: tekstovo-vizual'nye miniatiury [Arctic Nomads: Narrative-Visual Miniatures]. Ekaterinburg, Tipografiia “Al'fa Print".

Högselius, Per. (2012). Red Gas: Russia and the Origins of European Energy Dependence. New York, Springer.

Hughes, T.P. (1993). Networks of Power: Electrification in Western Society, 1880_ 1930. Baltimore and London, Johns Hopkins University Press.

Kandinsky, W.W. (1947). Point and Line to Plane: Contribution to the Analysis of the Pictorial Elements. New York, Solomon R. Guggenheim Foundation.

Larkin, B. (2013). The Politics and Poetics of Infrastructure. In Annual Review of Anthropology, 42 (1), 327-43. DOI 10.1146/annurev-anthro-092412-155522.

Law, J. (1986). On the Methods of Long Distance Control: Vessels, Navigation, and the Portuguese Route to Indiam. In Power, Action and Belief: A New Sociology of Knowledge? London, Routledge, Henley, 234-63.

Luehrmann, S. (2015). Religion in Secular Archives: Soviet Atheism and Historical Knowledge. Oxford and New York, Oxford University Press.

Nagy, Z. (2013). Television and Problems of Interpretating Cultural Phenomena Among the Vasiugan [Eastern] Khanty. In Anthropology \& Archaeology of Eurasia, 52 (3), 13-33. DOI: 10.2753/AAE1061-1959520302. 
Pelto, P.J. (1973). The Snowmobile Revolution: Technology and Social Change in the Arctic. Menlo Park, Calif., Cummings Pub. Co.

Prokofiev, G.N. (1927). Vyderzhka iz pis'ma G.N. Prokof'eva (Turukhansk 14/X - 26 g.) [Excerpts from the Letter of G. N. Prokof'ev (Turukhansk, 14/10/1926)], In Etnograf-issledovatel' [The Ethnographer-Researcher], (1), 38.

Rozentul, S. (1936). Problemy ispol'zovaniia energii vetra na Krainem Severe [The Problems of Wind Energy Use of in the Far North]. In RGAE [Russian State Archive of Economy]. 67/1/126.

Rozentul, S. (1937). Sravnitel'naia effektivnost' raznykh tipov energo stantsii na Krainem Severe [Comparative Efficiency of Different Kinds of Energy Plants in the Far North]. In RGAE [Russian State Archive of Economy]. 67/1/137.

Rytkheu, Iu. (1970). Ot zhirnika do atoma. Ob osvoenii raionov Krainego Severa. Ocherk. [From Seal-Oil Lamp to Atom. On the Development of the Far North. An Essay]. In Na Severe Dal'nem [On the Far North], (2), 11-15.

Sneath, D. (2009). Reading the Signs by Lenin's Light: Development, Divination and Metonymic Fields in Mongolia. In Ethnos: Journal of Anthropology, 74 (1), 72-90. DOI: $10.1080 / 00141840902751204$.

Ssorin-Chaikov, N. (2016). Soviet Debris: Failure and the Poetics of Unfinished Construction in Northern Siberia. In Social Research: An International Quarterly, 83 (3): 689-721.

Travin, N. (1939). Poliarnyi vetrokhod [The Polar Wind Vehicle], In Problemy Arktiki [The Problems of the Arctic], (2), 111-113.

Varshavskiy, A.A. (1937) Energetika Arktiki [The Energetics of the Arctic], In Sovetskaia Arktika [The Soviet Arctic], (2), 75-80.

Wells, H.G. (1921). Russia in the Shadows. New York, George H. Doran.

White, L.A. (1949). The Science of Culture: A Study of Man and Civilization. New York, Farrar, Straus.

Winther, T. (2008). The Impact of Electricity: Development, Desires and Dilemmas. New York, Berghahn Books. 


\section{Жизнь вне сети арктических кочевников: \\ социальное генерирование электричества \\ на Северном Ямале}

Д. В. Арзютов

Музей антропологии и этнографии им. Петра Великого РАН (Кунсткамера) Россия, 199034, Санкт-Петербург, Университетская наб., 3

$\overline{\text { Настоящая статья представляет собой попьтку этнографического анализа исто- }}$ рии и современной социальной жизни электричества у ненщев Ямала. На основании исторических документов и этнографических данных автор выстраивает картину электрификации севера полуострова, обращая внимание на сощиальные и культурные метаморфозы, которые происходят в среде оленеводов, и показывая, как эти изменения связаны в локальном, национальном и транснациональном измерении.

Ключевые слова: этнография, электричество, кочевники, ненщуы, освоение Севера, Арктика.

Работа выполнена при поддержке проекта РНФ «Энергия Арктики и Сибири: использование ресурсов в контексте сочиально-экономических и экологических изменений» (№ 18-18-00309).

Научная специальность: 07.00.07 - этнография, этнология и антропология. 